\title{
The International Relations Theory and Revolution: Epistemological Debates and Impacts on International Relations
}

\author{
Leyde Ernesto Rodríguez Hernández \\ Department of Specialty at the Higher Institute of International Relations, "Raúl Roa García", Havana, Cuba
}

Email address:

leyde@isri.minrex.gob.cu

To cite this article:

Leyde Ernesto Rodríguez Hernández. The International Relations Theory and Revolution: Epistemological Debates and Impacts on International Relations. International Journal of Environmental Protection and Policy. Vol. 7, No. 6, 2019, pp. 137-143.

doi: 10.11648/j.ijepp.20190706.11

Received: July 2, 2019; Accepted: August 6, 2019; Published: November 25, 2019

\begin{abstract}
The importance of the study of revolutions and the impact they have had on the evolution and dynamics of international relations, from its theoretical and conceptual aspect and its significance for the system of international relations, is explained. It is argued that the concept of Revolution has been approached with relative systematization by social theory and that there are different visions of the term, according to different ideological, classist and historical interpretations. It is also analyzed from the thinking logic of the different classical schools of International Relations Theory. The author considers that, one hundred years after the October Revolution, it is of vital importance for peoples, in an era characterized by the systemic crisis of the contemporary capitalist economy, which generates serious global problems: climate crises, food crises and political crises. With the multiple crises that humanity is going through, the international scenario could be marked by new revolutionary processes that Lenin called the weakest links in the imperialist chain. The specific characteristics of these changes could contribute qualitatively new elements for the construction of a pluripolar international system, as an alternative to the multipolar recomposition of international relations on the initiative of the United States and the European Union, powers interested in achieving a world balance of power, which serves to perpetuate the domination over the weakest states of the system and the practice of a coordinated policy towards the containment or regression of the global revolutionary phenomenon.
\end{abstract}

Keywords: Revolution, International Relations Theories, Fidel Castro, Third World, Global Problems

\section{Introduction}

In an interesting reflection entitled "Mubarak's luck is cast" Fidel Castro Ruz, the leader of the Cuban Revolution, analyzed that the world was facing simultaneously and for the first time three problems: climate crises, food crises and political crises [1]. But a little earlier, referring to "The serious food crisis," he wondered: "Will the United States be able to stop the revolutionary wave that is shaking the Third World? [2].

Rationality indicates that in these global conditions of climate crises, food crises and political crises, the United States would not have many possibilities or capacity to resist or stop a permanent revolutionary wave that shakes the Third World. Its powerful nuclear weapons, its satellites and its media power would be impotent and useless in the face of the revolutionary fervor of the peoples, regardless of the colors of their revolutions and the content of their demands.

At the beginning of the 21 st century, the United States also found it complex to contain the collapse of its empire, the cause, as the first imperialist power, of catastrophic wars for humanity and, of course, of the three essential problems mentioned by Fidel in his reflection.

Faced with the thrust of a world revolutionary situation unleashed by the global crisis of capitalism, revolution, and its impact on the transformation of international relations, takes on vital importance for the peoples. It is hoped that the new revolutionary processes that emerge throughout the $21 \mathrm{st}$ century will contribute to the radical change of current international relations, still under the control of a handful of powers that self-proclaim the International Community to keep the countries of the South in check, be it through the 
control of capital, the UN Security Council or with media or military power.

\section{Importance of Studying the Revolution}

Hence the importance of studying the Revolution, from its theoretical and conceptual point of view and its significance for transforming international relations more than ever. The concept of revolution has been approached with relative systematization by social theory and there are different visions of the term, according to different ideological, classist and historical interpretations.

From antiquity theorists of politics were interested in the problems associated with the cyclical change of power, the individual and collective efforts to overthrow a government by means of violence, as well as in the understanding of the moral and economic justifications of the revolution. Revolutionary sentiments within a state were usually attributed to a discrepancy between the wishes of the people and their perceptible situation, a divergence that gave rise to a certain political disagreement about the basis on which society should be organized and function.

Contemporary political theory was responsible for distinguishing between genuine revolutions and other phenomena that were often called by the same name, for example: coups d'état of a military nature or supported by the military, the illegal prolongation of the period of government of a leader or president, and other relatively sudden acts of seizure of power by small groups of highlevel individuals; various forms of popular, peasant, urban, religious revolts or rebellions and even the processes of political disintegration or rupture, known in their various forms: state, regional, colonial, ethnic or religious. However, none of these phenomena has a necessary or obligatory direct relationship with the real revolutionary change in society.

In the twentieth century bourgeois theoretical approaches to international politics analyzed revolution as a form of violent conflict in international relations. The school of political realism emphasized that revolutions are part of the conflictive dynamics of states and the inevitable struggle for power among the main protagonists of international politics.

The obviously realistic vision of Mark N. Hagopian defined revolution as a prolonged crisis in one or more of the traditional stratification systems (class, social condition, power) of a political community. It involves a deliberate and elite-led action to abolish or rebuild one or more of these systems through an intensification of political power and recourse to violence. [3]

In the same vein, for Crane Brinton and other pre-World War II theorists, revolutions took place when the gap between distributed political power and distributed social power within a society became intolerable. [4]

In such circumstances, the social classes that are experiencing some of the benefits of progress wish to develop more rapidly than through the possibilities granted by the system, and thus feel frustrated and paralyzed. Discontent over the distribution of economic results, social prestige and political power spreads, traditional values are openly questioned and a new social myth challenges the old one. Intellectuals become alienated from political life and gradually move from new criticisms to withdrawing loyalty to the political system. The ruling elites begin to lose confidence in themselves, in their beliefs and in their ability to direct and solve social problems; the old elites become too rigid to attract the emerging elites in their ranks and accelerate polarization.

Revolution also occurs when there is a profound contradiction between those who want to achieve rapid change and those who are opposed to change. According to some authors, the breaking point is reached when the instruments of social control fall, especially the army and the police, establishing alliances with the unhappy elements; or the government, in office, proves inept at using those instruments of social control. [5]

For their part, liberal or institutionalist approaches also perceive in revolutions events of a violent nature that disrupt the gradual and orderly evolution of society. These notions, guided by the theories of functionalism, were preeminent in the work of the American sociologist Talcott Parsons, who emphasized the need for consensus and equilibrium in society, observing in the conflict something rather abnormal, which breaks precisely with the social order. Parsons was more interested in the social order than in social change, in social statics than in the dynamics of processes, because for his school, conflict generates disturbing and dysfunctional consequences for society. [6]

In Europe, another aspect of this current, which tried to reconcile the study of equilibrium and social consensus with conflict, had a marked influence through the work of sociologists Max Weber, Ralf Dahrendorf [7] and Emile Durkheim. [8] Even with its recognised theoretical contributions on collective behaviour, social beliefs, political leadership and integration processes, functionalist thought was not characterised by its revolutionary character, but by its pragmatic aims aimed at solving society's immediate problems, in order to achieve the preservation of the capitalist social order. [9]

In one way or another, most sociologists influenced by Karl Marx's ideas have considered that conflict can serve positive or progressive social ends. The revolutionary conflict has been catalogued as a useful means for the resolution of disputes within a society and between nationstates on the international stage. Thus, many political scientists of this time accept conflict as a central explanatory category for the analysis of social change or progress, starting from a complete theorization of society in its aspects of continuity and change, which analyzes in class and economic conditioning the basis of all social contradiction and of the world revolutionary conflict. [10] 


\section{The Fundamental Scientific Conception on the Social Revolution}

This fundamental scientific conception on the social revolution is exposed in the work of Marx, Engels and Lenin. [8] A fundamental premise of Marxism has been that the sharpening of the contradictions of capitalism creates the conditions for the revolution that will defeat it and opens the way to a more just and solidary society, for which the abolition of private property was an essential objective, attending to the proposal contained in The Manifesto of the Communist Party. [11]

By analysing the situation of international relations in the mid-19th century, Marx and Engels diagnosed that the revolution would be led by the proletariat of the industrialised countries of Europe and, years later, Engels foresaw how the development of Western Europe operated against the violent struggle and in favour of parliamentary action by the working class. Later, Lenin led the Bolshevik Party to break "the weakest link in the imperialist chain", with the idea that it would be a contribution to the world revolution that would have its center in Germany, according to the logic of Marx's thought [12]

Social revolutions are determined by the objective laws of social development and, in contemporary times, have their origin in the economic, social and political contradictions of the capitalist system. Lenin was convinced that "revolutions are not made by commission, they cannot be made to coincide with this or that moment, but they mature in the process of historical development and explode in a moment conditioned by internal and external causes". [13]

In this way, the Leninist interpretation of revolutions indicates that, from the nineteenth century until today, Marx's philosophy constitutes a valid general theory to study the revolutionary movement of societies through the use of a certain number of specific instruments, categories or basic variables, among which are fundamental the concepts of mode of production and class struggle between exploited and exploiters. Marx's influence transcended far beyond the theoreticians or historians who interpreted the national and international spheres inspired by his ideas, since his work offers an integral and coherent methodological vision for the analysis of the dynamics of social processes in the epoch of the capitalist mode of production.

Curiously, the British Marxist historian Eric Hobsbawm [14] pointed out that the globalized capitalist world that emerged in the nineties of the twentieth century resulted, in many ways, enigmatically similar to the one that Marx had predicted in 1848 in The Communist Manifesto, but now, without a doubt, with more complexity due to the conflicts and global problems derived from the interaction of multiple phenomena of an economic, financial, military, technological and transnational nature accumulated by the capitalist system that generates them without a real perspective or possibility of solution. For that reason the importance of going to Marx and the just praise to his inevitable return in the current international conjuncture. [15]
The conditions that are source of the potential human conflict, that is to say the socioeconomic problems, the violent and aggressive impulses originated from the frustration when measuring the concrete against the ideal, the withdrawal and the alienation of the existing social structures, plus other similar factors in the epoch of Marx, are becoming more common on a planetary scale.

In almost every latitude of the world system, due to the expansive influence of information and communication technologies, the gap between the expected fulfillment oires) is widening among many nations, peoples and individuals, especially in the Third World: the Middle East, Asia, Africa and Latin America, regional scenarios in which the process of social, economic and political development is seldom able to provide satisfaction at the increasing rate of peoples' aspirations. As a whole, in therein almost every latitude of the world system, due to the expansive influence of information and communication technologies, the gap between the expected fulfilment of needs and the concrete consummation of needs (aspirations or desires) is widening among many nations, peoples and individuals, especially in the Third World: the Middle East, Asia, Africa and Latin America, regional scenarios in which the process of social, economic and political development is seldom able to provide satisfaction at the increasing rate of peoples' aspirations. As a whole, in these geographical regions (with two thirds of humanity in underdevelopment, poverty and marginalization), inequality with respect to the developed North increases, as well as the real possibility of a revolutionary wave.

\section{Revolution in the World-system of the 21st Century}

The current era offers a globalized capitalist system and impressive advances in scientific-technological renovation; the classist and economic problems synthesized in the NorthSouth conflict or contradiction occupy an outstanding plane in the dynamics of international relations.

This conflict represents a tendency that increased after the disappearance of the East-West confrontation, which dominated the international context during the prolonged Cold War. The gap between rich and poor or between North and South tends to increase at an unprecedented rate, because the developed capitalist countries, where just over $20 \%$ of the world's population resides, appropriate or benefit from $80 \%$ of the planet's productive or natural wealth. In the last decades of the 20th century and in the first decade of the 21 st, neoliberal economic policies deepened the abyss and plunder that alienated underdeveloped countries from the central powers of world capitalism.

Related to the North-South conflict, serious global problems appear, such as the exponential demographic growth in the third world regions and the scarcity of food, precisely when the planet enters a critical phase due to the exhaustion of non-renewable natural resources. In addition, 
the ecological crisis due to the deterioration of the environment, the pollution of the seas, rivers, the reduction of forests, the affectation of the ozone layer in the upper atmosphere and the evidence of climate change with the gradual melting of the large masses of ice concentrated in the polar ice caps and the consequent global warming, which threatens a terrible catastrophe with unforeseeable consequences for the survival of the human species.

These problems that afflict the planet are a direct consequence of unbridled exploitation and capitalist barbarism. The greatest responsibility for this state of affairs lies with the most developed countries in the system, which achieved high levels of economic expansion on the basis of a model of life and a highly consumerist and wasteful economy.

Faced with the desolate panorama of the capitalist system, particularly its poor and underdeveloped periphery, social scientists return to Marx's thinking to adopt new socioeconomic models that make more efficient use of human and natural resources and contribute to conserving or renewing them with sustainable development policies for the benefit of humanity.

Large popular sectors of the United States and the European Union suffer the economic inequalities and injustices of capitalist societies in the so-called technotronic or post-industrial phase, divided into antagonistic social classes. Even in the times of economic globalization, the process of capitalist development always produces perverse and asymmetrical effects in relation to the benefits obtained by peoples. The rupture or disconnection with the traditional mechanisms of capitalist domination plays a crucial role in the growth of the potential for revolutionary conflict engendered by the contradictions between rich and poor, or between a privileged minority and the majorities under the dictatorship of capital.

Revolution will be inevitable in the world-system of the 21 st century, for throughout history class conflict has been the engine of social change. Revolutions are the only possible way to resolve the antagonistic contradiction between rich and poor within societies and in the transformation of international relations towards a truly democratic, just and human system.

In Marxism and Lenin's ideas lies the theory and strategy of the revolution, because, as Che pointed out: "in short, we must bear in mind that imperialism is a world system, the last stage of capitalism, and that it must be defeated in a great world confrontation. The strategic aim of this struggle must be the destruction of imperialism [...] The fundamental element of this strategic aim will be, then, the real liberation of de peoples". In Che's thought only through revolution could a more solidary social order be reached, the abolition of capitalism and the formation of a "new man". [16]

In light of current events in Venezuela, Bolivia, Ecuador, Nicaragua, El Salvador, and other Latin American countries, and even of the non-traditional transformative processes of the Latin American revolutionaries of the twentieth century, it could be said that the seizure of political power by the exploited does not necessarily entail violence or revolutionary war. Marx was aware of the role of violence in history, but considered it less important than the contradictions inherent in the old society for the achievement of the ultimate end of the proletarians and exploited: the defeat of capitalism.

The German philosopher foresaw a series of increasingly intense clashes between the proletariat and the bourgeoisie (exploited and exploiters) until the eruption of a revolution that would eventually lead to the overthrow of the bourgeoisie and the building of a socialist society. With its own dynamics and specificity, in different regions and countries of the international system, the inevitable collision between antagonistic social classes would be a variable of change and human emancipation in the 21 st century.

\section{Interesting Results}

Marxist theorists have not offered a comprehensive and systematic study of the impact of revolutions on the system of international relations of this era. Some political scientists agree that the modern world-system has been shaped largely by revolutions, conflicts and wars. [17]

The last four centuries were marked by great and historic revolutions of a bourgeois, socialist and/or national liberation character. For Marxist theorists, revolutions are the locomotives of history because they accelerate the processes of development and human progress. Since the 17th century revolutions have made important contributions to the development of modernity. Not only have they promoted political and social transformations within nations, but also the very dynamics of international relations.

The current international system is the result of the geographical expansion and complexity of the system of states that emerged in Europe in the seventeenth century, after a long historical process initiated, approximately, in the fourteenth and fifteenth centuries and that would convulse that continent.

In short, the international system is a consequence of the emergence of capitalism, which established new political structures and created modern national-territorial states, which concretized in practice the political aspirations of the intellectuals of the Renaissance and of the ascending bourgeoisie as the ruling class. The seventeenth, eighteenth and nineteenth centuries were the scene of the expansion of that system to encompass the five continents.

The triumphant European capitalism, with more consolidated technology, science and political institutions submitted to its colonial domination the territories "discovered" and conquered by the force of arms in America, Asia and Africa. The historical revolutions that impacted those centuries and influenced the evolution and conformation of a system of international relations were the following:

- 17th century: Dutch and English revolutions.

- In the 17th century: North American, French, Haitian revolutions and their aftermath in the independence 
revolutions in Latin America at the beginning of the 19th century.

- 19th century: European revolutions of 1848 [18] and the Paris Commune in 1871. [19]

The expansion of capitalism created the world market and brought together the most distant regions of the planet on the basis of the most brutal exploitation, looting, genocide of indigenous populations and the imposition of European culture. In this historical period, new States emerged on the subjugated continents, with the consent of Europe or for the struggle of the peoples for their independence. The inclusion of the American republics in the European international system, which extended their recognition of their rights, was the first major expansion of the system which, until the beginning of the 20th century, would maintain its hegemonic centre in the dominant bourgeois Europe.

At the end of the 19th century, in the midst of the development of monopoly capitalism in its imperialist phase, two new powers, one in America (the United States) and the other in Asia (Japan), challenged Europe's international supremacy. The international system at the dawn of the 20th century began to become global and the hegemonic center began a shift to other continents.

In this context, the revolution that took place in Russia on October 25, 1917, according to the Julian calendar (November 7 in the Gregorian calendar), distinguished from other revolutions by its world character, was the most important political event of the twentieth century: it represented a radical turn in the history of humanity, a turn from the old capitalist system to socialism; it was the first time that the proletariat triumphed and seized power. This elevated to the scale of fundamental objective not that one form of exploitation replaced another or that one group of exploiters replaced another group of exploiters, but the suppression of all kinds of exploitation of man by man, the suppression of each and every exploiting group, the organization of a new society, of socialist society without classes. The Great Socialist Revolution of October opened for humanity a new era of possibilities towards the construction of socialism.

Its impact was palpable both in America and in Europe. Although the revolution did not expand socialism as an immediate effect, it gave other troubled Third World countries an example to follow. In order to understand the evolution of international relations in the 20th and $21 \mathrm{st}$ centuries, it is essential to analyze how the October Revolution contributed to national liberation and the construction of popular democracies of other peoples, such as Cuba, China, Vietnam or Guyana. The heroic days of October - as described by the North American journalist John Reed - shook the world. [20] No later fact has been able to diminish the prowess of the Russian Bolsheviks, who knew how to combine the highest European political intellectuality with the revolutionary spirit of the Russian working class and the struggle of the peasants for land and their rights. Those actions constituted an imperishable example in the dispute of the peoples for the conquest of freedom.
Because of the transcendence of the revolutions that shook the world -the October Revolution or Soviet Revolution in 1917, the Chinese Revolution in 1949 and the Cuban Revolution in 1959, among others of national liberation in the Third World- the 20th century inaugurated a new era in international politics. The powerful anti-colonialist and antiimperialist movement that developed, particularly after 1945, dealt the final blow to the old colonial system of the main capitalist metropolises. This historic process led to the formation of new independent states on almost every continent, mainly in the Third World. For the first time in the history of international relations, the international system reached an effectively global or planetary dimension.

Revolutions have an immediate influence beyond the national borders of states, introducing historical leaps and social upheavals that determine or condition the foreign policy of countries through a kinematics of continuity and change, which affects the global scope of international relations and contributes to the evolution and formation of the international system. Today it is a system made up of more than 190 interacting States, to which is added a multiplicity of transnational entities, not directly State, with political influence, in some cases greater than the individual foreign policy of many States.

The international system remained basically heterogeneous despite the collapse or strategic renunciation of the Soviet Union and the European socialist bloc, which determined the end of the East-West confrontation and a conjunctural change in the correlation of forces, in favour of the capitalist system and the United States intoxicated in its unipolar leadership. These abrupt modifications of the world geostrategic map placed the capitalist economic-social formation in an unquestionable supremacy during a certain historical period.

However, the international system continues in an era of transition from capitalism to socialism, since in it there still coexist, in a dilemma of cooperation and hostility, capitalist, imperialist, socialist, developed and underdeveloped states, with regimes of various kinds: reactionary and revolutionary. It should be noted that, since the appearance of the capitalist market that gave rise to imperialism, the dynamics of international politics ceased to develop only among states, since internationalist solidarity among peoples, societies and dissimilar social sectors, fighting for a better and possible world, has begun to overflow national frameworks to become an essential force in the revolutionary transformation of international relations. At the same time, these facts are intertwined from the confrontation of the capitalist transnationals independent of their States.

\section{Conclusion}

With the multiple crises that humanity is going through, the international scenario could be marked by new revolutionary processes that Lenin called the weakest links in the imperialist chain. The specific characteristics of these changes could contribute qualitatively new elements for the construction of a pluripolar international system, as an 
alternative to the multipolar recomposition of international relations on the initiative of the United States and the European Union, powers interested in achieving a world balance of power, which serves to perpetuate the domination over the weakest states of the system and the practice of a coordinated policy towards the containment or regression of the global revolutionary phenomenon. [21]

In this scenario, the revolutions in Cuba, Venezuela, Ecuador [22] and Bolivia represent the agreement of an advance of the South American pole towards the construction of poles of plural power and ideals. These diverse but deeply anti-imperialist revolutions favor a genuine process of construction of socialism in the $21 \mathrm{st}$ century, when imperialism still presupposes the antechamber of social revolution, as Lenin warned in 1917. But now in a more globalized proportion of the North-South conflict in international relations.

The military intervention in Libya, the growing military interventionism in Syria and the threats against Iran have been part of the opportunist responses of the United States and the European Union to the collapse of their system of domination and plunder in North Africa and the Middle East, as genuinely popular movements emerged in Tunisia, Egypt and other countries. All this was also interrelated with the strategy of the imperialist powers to seize large reserves of oil, water and confiscate financial assets in times of serious economic and social crisis of the capitalist system. The most recent examples of popular insurrections in Tunisia and Egypt testify to the rebellion of the peoples against capitalist domination. And it is only an advance, or an advance, whatever you want to call it. [23]

\section{References}

[1] Castro Ruz, Fidel. Mubarak's luck is cast, Cubadebate, 2011: $<$ http://www.cubadebate.cu/reflexiones-fidel/2011/02/01/lasuerte-de-mubarak-esta-echada/\#.U6SzJGVJk2Q> [25/1/2016].

[2] Castro Ruz, Fidel. The serious food crisis, Cubadebate, 2011: $<$ http://www.cubadebate.cu/reflexiones-fidel/2011/01/31/lagrave-crisis-alimentaria $>[1 / 3 / 2016]$.

[3] Hagopian, Mark N. The Phenomenon of Revolution and International Politics, Dodd Mead, New York, 1974: en Dougherty, James E. y Pfaltzgraff, Robert L. in Theories at odds in international relations, Latinoamericano Publishing House, Buenos Aires, 1993: p. 323.

[4] Brinton, Crane. Anatomy of Revolution, Norton, New York, 1938.

[5] Edward, Lyford P. The Natural History of Revolution, University of Chicago Press, Chicago, 1927.

[6] Parsons, Talcott. The Structure of Social Action, The Free Press, New York, 1937.

[7] Dahrendorf, Ralf. Classes and class conflict in industrial society, Rialp, Madrid, 1962.

[8] Durkheim, E. The rules of sociological method, Economic
Culture Fund, México D. F, 2001.

[9] Ibarra Viñas. Theories of classical authors. Durkheim, Marx y Weber. https://www.monografias.com/trabajos15/autclasicos/aut-clasicos.shtml [1/3/2019].

[10] Engels, F. Origin of the family, private property and the State, Social Sciences Publishing House, Havana, 1975; Engels, F. Ludwig Feuerbach and the End of German Classical Philosophy, Federico Engels Foundation for Socialist Studies, Madrid, 2006; Lenin, Vladímir I. The State and the Revolution, Political Publisher, Havana, 1963.

[11] Marx, K. y F. Engels. The Manifesto of the Communist Party, Political Publisher, Havana, 1982.

[12] Lenin, Vladímir I. "Imperialism, the higher phase of capitalism", in Vladimir I. Lenin: Selected Works, t. 1, Progreso Publishing House, Moscow, 1961, pp. 689-793.

[13] Lenin, Vladímir I. Report at the Moscow provincial conference of factory committees, 23 July, in Vladimir I. Lenin: Selected Works, t. 3, Progreso Publishing House, Moscow, 1961, pp. 23-37.

[14] Hobsbawn, Eric. Marx and globalization. Rebelión, $<$ http://www.rebelion.org/noticia.php?id=28648> [27/2/2016].

[15] Cassidy, John. The Return of Karl Marx, The New Yorker, 20-27 October, New York, 1997, p. 248 and Valdés Vivó, Raúl. Indeed, Marx is returning: an article in the U.S. press and essential clarifications, Political Publisher, Havana, 1998.

[16] Guevara, Ernesto Che. Message to the peoples of the world through the Tricontinental, in Writings and Speeches, t. 9, Ciencias Sociales Publishing House, Havana, 1977, pp. 355372 and Guevara, Ernesto Che. Socialism and Man in Cuba, in Ernesto Che Guevara in Writings and Speeches, t. 8, Ciencias Sociales Publishing House, Havana, 1977, pp. 253-272.

[17] Arendt, Hannah On Revolution, Viking, Nueva York, 1965; and Halliday, Fred. Revolution and World Politics: "The Sixth Great Power": Revolutions and the International System", Rethinking International Relations, Macmillan, London, 1994, pp. 124-146.

[18] The history of Europe from 1789 to 1848 is the history of the great economic, social and political transformations that definitively established industrial capitalism. Hobsbawn, Eric. The bourgeois revolutions, People and Education Publishing House, Havana, 1982.

[19] Marx and Engels made extensive use of the experience of the revolutionary movement during the last third of the nineteenth century to develop their theory of the "dictatorship of the proletariat. Marx, K. The Civil War in France, in Carlos Marx and Federico Engels: Selected Works, t. II, Progreso Publishing House, 2001, pp. 104-142; Marx, K. Criticism of the Gotha Program, Social Sciences Publishing House, Havana, 1975; Marx, K. y Engels, F. El Capital, The Capital, t. II and III, Social Sciences Publishing House, Havana, 1986; Engels, F. Anti-Duhring, Publishing House Pueblos Unidos, 1961, Montevideo.

[20] Reed, John. Ten days that shook the world, Txalaparta Publisher, Navarra, 2006.

[21] Rodríguez Hernández, Leyde E. A century of International Relations Theory, Félix Varela Publisher, Havana, 2017. 
[22] In the case of Ecuador, the "Citizen Revolution" was betrayed by President Lenin Moreno, Rafael Correa's successor, opening another stage of neoliberal economic policies and subordination to the regional strategy of U.S. domination in Latin America. Borón Atilio. The Betrayal of Lenín Moreno. http://www.atilioboron.com.ar/2018/01/la-traicion-de-leninmoreno.html [23/3/2019].

[23] Rodríguez Hernández, Leyde E. Links between the operations
"Dawn Odyssey", "Harmattan" and the "Southern Mistral" exercise against Libya, Cubadebate, $<$ http://www.cubadebate.cu/especiales/2011/03/23/nexosentre-las-operaciones-odisea-del-amanecer-harmattan-y-elejercicio-southern-mistral-contra-libia/\#.V viQFKJr9o> [15/3/2019] and "The geopolitical on the war against Libya, http://leyderodriguez.blogspot.com/2011/11/la-perspectivageopolitica-en-la-guerra_25.html [23/3/2019]. 